\title{
The UNCLOS and the US-China Hegemonic Competition over the South China Sea
}

\author{
Kamrul Hossain*
}

The South China Sea is a semi-enclosed sea with a complex set of territorial claims by a number of Southeast Asian nations and China being the dominant claimant country. The United States is not a party to such claims. However, the US has great concerns pertaining to peace and stability of the region as far as freedom of navigation in the SCS is concerned, which has significant repercussions for its strategic interests. In addition to the utilization of the SCS as an important international trade route, the US is also committed to protect the interests of its allies in the region, as well as those of its companies involved in offshore hydrocarbon activities. In the aftermath of the September 11 terrorist attack, the dynamics of a new world order push the US to strengthen its presence in the region in order to combat any security threats against its interests. This article investigates China-US relations in the SCS and highlights the law of the sea prescriptions that facilitate the understanding of the legal nature of the tensions between China and the US.

\section{Keywords}

UNCLOS, South China Sea, US-China Conflict, U-shaped Line, Strategic Partner, Security Interest

* Senior Researcher at the Northern Institute for Environmental and Minority Law in the Arctic Centre of the University of Lapland, Finland. LL.B. (Dhaka), LL.M. (Helsinki/Aix-Marseille-III), LL.D. (Lapland). The author may be contacted at: khossain@ulapland.fi / Address: PO Box 122, Arctic Centre, University of Lapland, Fin-96101 Rovaniemi, Finland. 


\section{Introduction}

Geopolitical and maritime interests in and around the South China Sea ("SCS") have created a complex set of claims concerning rights, obligations and jurisdiction over the sea. The potential for hydrocarbon resources, importance in maritime navigation, significance for international trade and transport security in the sea, as well as strategic interests pertaining to balance of power, are the driving forces that mark the significance of these dynamics. In particular, territorial claims over the SCS are among the most contested ones in the whole world. By nature, the SCS is a semi-enclosed sea rich in diverse living and non-living resources. It is located in the south of China, bordering Vietnam and Malaysia in the west; Brunei, Malaysia, and Indonesia in the south; the Philippines in the east; and Taiwan in the north. Six of these seven countries bordering the sea are involved in the conflicts pertaining to the territorial claims and contestations over the SCS. ${ }^{1}$

While geographically the US is not a part of these territorial disputes, it still has significant maritime interests in the SCS in terms of both freedom of navigation and security for maritime trade and transportation. For the US, the SCS, because of its maritime route connecting the Pacific Ocean in the east and Indian Ocean in the south, also promotes strategic cooperation - both military and economic - with the nations in the region. In addition, there are other elements directly linked to US interests in the SCS. These include the protection of the interests of American companies involved in hydrocarbon exploration and exploitation activities; the US is strategically present in the region in order to pre-emptively combats any potential security threats against its interests, ${ }^{2}$ as well as those of its allies. These factors have propelled the US to engage itself in the tensions surrounding the SCS disputes.

Primarily, therefore, the objective of this research is to investigate the on-going competition between the two hegemonic powers - the US and China-over the SCS within the limited context of the law of the sea. It is important to note that in the SCS region, geopolitical dynamics, while motivated by numerous facts, are largely

1 J. Burgess, The Politics of the South China Sea: Territoriality and International Law, 34 Security Dialogue 8 (2003). This complexity is grounded on a number of reasons: First, because of the number of parties involved in the disputes either directly or indirectly; second because of its geo-political and strategic importance; and third because of its economic resource potential. See L. Bautista, Thinking Outside the Box: The South China Sea Issue and the United Nations Convention on the Law of the Sea (Options, Limitations and Prospects), 81 PhiLIPPINE L. J. 707 (2006).

2 After the September 11 attacks that destroyed the twin tower in the US, the dynamics of a new world order push the US to strengthen its presence in the region in order to act pre-emptively to combat security threats. See "State of Union" address delivered by the President Bush, Jan. 28, 2002, available at http://whitehouse.georgewbush.org/ news/2003/012803-SOTU.asp (last visited on Apr. 6, 2013). 
associated with the law of the sea. However, a detailed discussion on the overall legal merits of the disputes involving the regional actors, or the initiatives of the settlement process of such disputes, is not the main focus of this article. Instead, the article examines how the provisions of the law of the sea, particularly the United Nations Convention on the Law of the Sea ("UNCLOS"), play a role in the relationship between China on one hand and the US on the other, in the context of maritime interests over the SCS. As far as the US interests interact with those of its other allies in the region, reduced tensions between these two rivalries may play a significant role. It is, therefore, important to discuss how the provisions of UNCLOS apply to the disputes in the SCS and how the law of the sea shapes the interests and relationship of both China and the US and with other regional actors. In order to clarify US involvement in the disputes, however, a brief understanding of the historical background of the SCS disputes is important.

This article is composed of six parts, including the Introduction and Conclusion. Part two will investigate the background of the disputes and the on-going tensions between China and the US over the disputes. Part three will examine how Chinese and other coastal States' interests are shaped by the disputes, which will facilitate understanding of the involvement of the US in the disputes. Part four will focus on the US policy pertaining to its geostrategic and legitimate interests over the SCS. Part five will finally analyze the hegemonic competition between China and the US and the role of UNCLOS in framing the relationship between the two over the SCS disputes.

\section{Background of the Conflicts over the SCS}

\section{A. Geographical Overview of the SCS}

The SCS is covering an area of 3.5 million square kilometres, ${ }^{3}$ often regarded as the 'maritime heart' of Southeast Asia. The sea connects the Pacific Ocean in the east, to the Indian Ocean in the south. Many of Asia's influential States are among its littoral countries, including China, Brunei, Cambodia, Indonesia, Malaysia, the Philippines, Singapore, Taiwan, Thailand, and Vietnam. ${ }^{5}$ The continents of Asia, Africa, Europe,

3 Y. Wang, Rethinking the South China Sea Issues: A Perspective of Sino-U.S. Relations, 21 PACIFIC Focus 108 (2006).

4 L. Boonpriwan, The South China Sea Dispute: Evolution, Conflict Management and Resolution, ICIRD 2012, available at http://www.icird.org/2012/files/papers/Lalita\%20Boonpriwan.pdf (last visited on Apr. 6, 2013).

5 C. Joyner, The Spratly Islands Dispute in the South China Sea: Problems, Policies, and Prospects for Diplomatic Accommodation, 55, available at http://www.stimson.org/images/uploads/research-pdfs/cbmapspratly.pdf (last visited 
and Australia are linked through the SCS. There are two sets of small islands located within the water body of the SCS, such as south of China's Hainan Island (situated approximately 150 nautical miles) and the Paracel Islands (consisting of more than 20 islands, cays, atolls, reefs, banks, and shoals). These islands, which are seasonally inhabited by Chinese visitors and settlers, have historically served as fishing grounds, as well as for other economic activities of Chinese fishermen, until South Vietnam's invasion in the 1950s and early 1970s. ${ }^{6}$ Although these island groups have been claimed by both China and Vietnam, they have been under Chinese control since the battle at sea in 1974 between China and South Vietnam. ${ }^{7}$ A second set of islands, the Spratly Islands, is located south of the Paracel Islands, southwest of the Philippines, and north of Malaysia and Brunei. This island group consists of more than 230 islands and perhaps as many as 400 islets, cays, reefs, atolls, banks, and shoals, dispersed over $250,000 \mathrm{~km}^{2}$ of the SCS. However, none of these islands and other features is permanently inhabitable.

Figure 1: The Islands in the South China Sea ${ }^{9}$

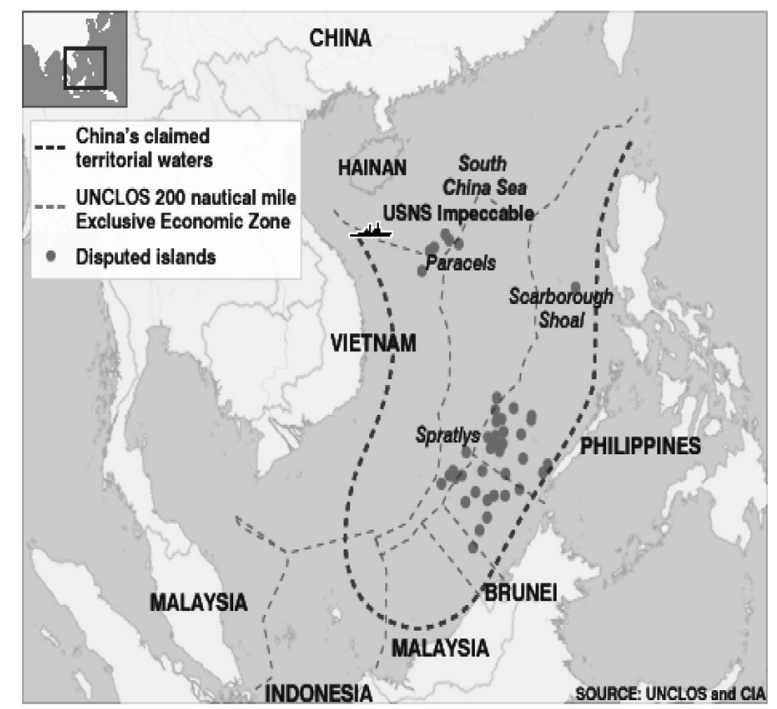

on Apr. 6, 2013).

6 J. Shen, China's Sovereignty over the South China Sea Islands: A Historical Perspective, 1 ChINESE J. INT'L L. 98 (2002).

$7 \quad$ Id. at 98.

$8 \quad$ Id. at 97.

9 See UNCLOS and CIA (reproduced in East Sea/South China Sea Studies), available at http://southchinaseastudies.org/ en/conferences-and-seminars-/515-the-south-china-sea-avenue-towards-a-resolution-of-the-issue (last visited on Mar. 24, 2013). 


\section{B. Historical Evolution of the Disputes}

The core of the SCS disputes lies in China's sovereignty claims virtually over the entire water body of the sea. The claims are presented by China through its 'U-shaped' demarcation line. ${ }^{10}$ Their historical origin can be divided into pre-twentieth and posttwentieth century's practices. In the pre-twentieth century, it is argued, the whole of SCS used to be regarded as 'maritime commons' - a shared area whose resources are open for all, despite the fact that Chinese merchants, traders, fishermen, and pirates arguably dominated much of this area over the last thousand years. ${ }^{11}$ However, other peoples also used this area. There has been no established State control over this area, even though Vietnam claims part of the Paracel Islands, based on its planting of a flag and construction of a stele and other marks of authority dating back from 1816. Scholars argue that even if an action such as planting of a flag was conducted, it was not done as part of an act of State, for no State had any control over the islands. ${ }^{12}$ A range of people, including both Chinese and Vietnamese, used to stay in the larger islands for an extended period of time, but without making any permanent settlements. In most cases the islands were used as fishing grounds for the fishermen, which never excluded other people in the islands. ${ }^{13}$

In the early twentieth century, however, China and France claimed the islands and water body of the SCS, based on historical practice in 1902 and 1931, respectively. Up until the end of the Second World War, meanwhile, a series of events took place that propelled Japan to protest against French claims and to pursue its own claim over part of the area. In 1946, the Republic of China occupied Taiping Island, the largest of the Spratly Islands, and placed a garrison there. Since this period, a whole series of claims have eventually been made by other nations surrounding the SCS, including Vietnam, the People's Republic of China ("PRC"), the Republic of China (Taiwan), the Philippines, Malaysia, and Brunei. ${ }^{14}$

\section{The Current US-China Conflicts in the SCS}

The US does not have any direct bearing on the territorial claims or the sovereignty

10 See Conflict over the South China Sea: Identity Politics Meets History, Policy Commentary - March 2012, Sigur Center for Asian Studies, The George Washington University, available at http://www.risingpowersinitiative.org/ wp-content/uploads/policycommentary_mar2012_southchinasea.pdf (last visited on Mar. 24, 2013). 
disputes over the ownership of the SCS islands. It has, however, geostrategic concerns on any deterioration of the situation among the SCS - surrounding nations. Nevertheless, the US claims of its right to navigation, innocent passage, and other legal entitlements in the SCS are appropriate within the law of the sea. This geopolitical position has finally led the US to compete with China in this region.

The contested issue between China and the US is over the Chinese claim of sovereignty around the U-shaped line in the SCS that the US argues is not compatible with the law of the sea, particularly with the provisions of UNCLOS. According to the US, neither UNCLOS nor international custom negates the rights of all States to conduct lawful maritime exercises, including military activities in the Exclusive Economic Zones ("EEZs"), without notice or the coastal State's consent. ${ }^{15}$ China, on the other hand, insists on its claim of sovereignty over the whole of the SCS, arguing that any activities undertaken in the SCS without prior notification or its permission violate its domestic law and international law. ${ }^{16}$ Serious direct tensions on this contested question have already been evidenced twice in recent times, first in $2001^{17}$ and then in $2009{ }^{18}$ in response to alleged harassment of the US naval ships by China. ${ }^{19}$

Besides, territorial sovereignty disputes between China and other disputant nations are expected to have the potential to affect the Sino-US relations. The most likely event might be a conflict between China and the Philippines, where the US could be involved by virtue of its 1951 Mutual Defense Treaty with the Philippines. According to the treaty, each party recognizes that an armed attack in the Pacific area on either of the parties would be dangerous to its own peace and safety, and declares that it would act to meet the common dangers in accordance with its constitutional

15 B. Glaser, Armed Clash in the South China Sea, 14 Contingency Planning Memorandum (2012), Council on Foreign Relations, available at http://www.cfr.org/east-asia/armed-clash-south-china-sea/p27883 (last visited on Mar. 24, 2013)

$16 I d$. at 2.

17 It is known as EP-3 incident, which occurred in 2001 in the air space of the SCS, where the EP-3 - a US navy surveillance plane - collided with a Chinese F-8 fighter jet, in international air space, approximately seventy miles off of Hainan Island. After the collision, the US crew made an emergency landing at Lingshui Military Airport on the Hainan Island. According to the US, China detained the aircrafts' twenty-four American crew members for eleven days. China and the US accused each other for the accident and for the violation of international law. See D. Tian and C. Chao, The American Hegemonic Responses to the U.S.-China Mid-Air Plane Collision, 2 InT'L J. CommC'N 1-2 (2008); S. Kan et al, China-U.S. Aircraft Collision Incident of April 2001: Assessments and Policy Implications, CRS Report for Congress, Oct. 10, 2001, available at http://www.fas.org/sgp/crs/row/RL30946.pdf (last visited on 6 Apr. 2013).

18 In this later event, in March 2009, five Chinese vessels surrounded a US military surveillance ship seventy-five miles off of Hainan Island to the south and forced it to stop directly in its path. The incident has been coined as 'China's harassment' of US vessels. See A. Tyson, U.S. protests China's 'harassment' of Navy ship, WASH. Post, available at http://articles.sfgate.com/2009-03-10/news/17212093_1_chinese-ships-pentagon-vessels (last visited on Apr. 6, 2013). See also C. Thayer, The United States and Chinese Assertiveness in the South China Sea, 6 Security Challenges 74-75 (2010).

19 Id. at 74 . 
process. ${ }^{20}$ The contingency between China and the Philippines would rise from the exercise of hydrocarbon development in the disputed area of Reed Bank, which is part of the Spratly Islands and located eight nautical miles from Palawan Island of the Philippines. ${ }^{21}$ Chinese vessels would have increasingly harassed oil survey ships operating in the Reed Bank. As plans for drilling for gas in the Reed Bank move ahead, potential Chinese responses would possibly escalate violence in the region. A similar violence may also erupt from other actions and disputants in the region, e.g., from Vietnam. ${ }^{22}$

While the contested question between China and the US is about maritime rights over the SCS in accordance with the law of the sea, ${ }^{23}$ the US has also become an active partner in the territorial disputes to the extent that the facilitation of a peaceful settlement of the disputes is concerned. ${ }^{24}$ The resolution of the disputes (which necessarily involves questions pertaining to the provisions of UNCLOS) would guarantee peace and stability in the region where the US interests lie in ensuring its freedom of navigation and other commercial rights in accordance with the law of the sea.

20 The U.S.-Philippines Mutual Defense Treaty art. IV. For the full text of the Treaty, see Mutual Defense Treaty between the United States and the Republic of the Philippines, Aug. 30, 1951, available at http://avalon.law.yale. edu/20th_century/phil001.asp (last visited on Apr. 6, 2013).

21 Such contingency can be evidenced by Manila's recent move to bring the dispute before the UN. See Philippines to bring South China Sea dispute with Beijing to tribunal, THE Guardian, Jan. 22, 2013, available at http://www.guardian. co.uk/world/2013/jan/22/philippines-south-china-sea-beijing (last visited on Apr. 6, 2013). See also Philippines summons China's ambassador over South China Sea standoff, The Telegraph, Apr. 11, 2012, available at http://www. telegraph.co.uk/news/worldnews/asia/philippines/9197077/Philippines-summons-Chinas-ambassador-over-SouthChina-Sea-standoff.html (last visited on Apr. 6, 2013).

22 R. Sutter, United States and China: Will positive relations endure?, East Asia Forum, Sept. 13, 2010, available at http:// www.eastasiaforum.org/2010/09/13/united-States-and-china-will-positive-relations-endure (last visited on Apr. 6, 2013).

23 This reiteration has also done in 2010 when the Secretary of the State Hilary Clinton while speaking with the support of a dozen other Asia-Pacific nations. See S. Lawrence \& T. Lum, U.S. China Relations: Policy Issues, CRS Report for Congress 27, Mar. 11, 2011, available at http://assets.opencrs.com/rpts/R41108_20110311.pdf (last visited Apr. 6, 2013).

24 This stance of the US was confirmed at the 18th ASEAN Regional Forum meeting held in Bali on July 23, 2011 where the Secretary of State, Hilary Clinton, stated that the US has effectively established itself as a de facto party in the facilitation of a peaceful settlement of the disputes - the disputes to be set aside in accordance with the law of the sea including the rules of UNCLOS. See D. Singh, South China Sea Developments at the ASEAN Regional Forum, East Asia Forum, Aug. 3, 2011, available at http://www.eastasiaforum.org/2011/08/03/south-china-sea-developments-atthe-asean-regional-forum (last visited on Apr. 6, 2013). 


\section{The Chinese and Other Coastal States' Position over the SCS}

\section{A. The Chinese Position}

China's claim over the SCS is primarily based on historical grounds. ${ }^{25}$ According to China, it was the first country to discover the islands and utilize them as a resource. ${ }^{26}$ It has been argued that the discovery of these islands took place as early as the second century B.C. Proof of this discovery may be found in Chinese folk songs, old books, various other Chinese official and unofficial accounts, as well as in maps drawn by official Chinese authorities. ${ }^{27}$ These claims are supported by various other facts, such as fishing in the SCS. China maintains that its fishermen have exploited fishing resources in the SCS for centuries. They have also kept detailed records of navigation routes, as well as the names of islands, islets, and shoals in the SCS. ${ }^{28}$ In April 1935, China tried to publish a new map in response to actions taken by the French colonial power in Vietnam in its effort to occupy the Spratly Islands. This suggests China's effective control over the islands. ${ }^{29}$ Throughout the Second World War, Japan occupied the Spratly Islands. However, China recovered them in $1946 .{ }^{30}$ China has also argued that, until the 1930s, its control over the SCS islands and their surrounding waters was peaceful until France seized the opportunity to occupy and annex several islands. ${ }^{31}$

After the Second World War, the government of the Republic of China (Taiwan) published two maps of the SCS, first in 1947 and then in 1948. The 1947 map depicted archipelagos, islands, as well as other features of the SCS. For the first time, the map contained the eleven dots in the shape of a 'U.'(Figure 2)

\footnotetext{
25 M. Li, Reconciling Assertiveness and Cooperation?: China's Changing Approach to the South China Sea Dispute, 6 Security Challenges 42 (2010).

26 Id. at 53.

27 Id.

28 Id. The proof of such exploitation of resources can be found in the historical and archaeological incentives, such as the abundant evidence that the Chinese fishermen had been using in the islands of Paracels and Spartlys.

29 Id. at 54.

30 Id. at 54.

31 Supra note 6, at 98.
} 
Figure 2: 11 Dotted Lines in the South China Sea ${ }^{32}$

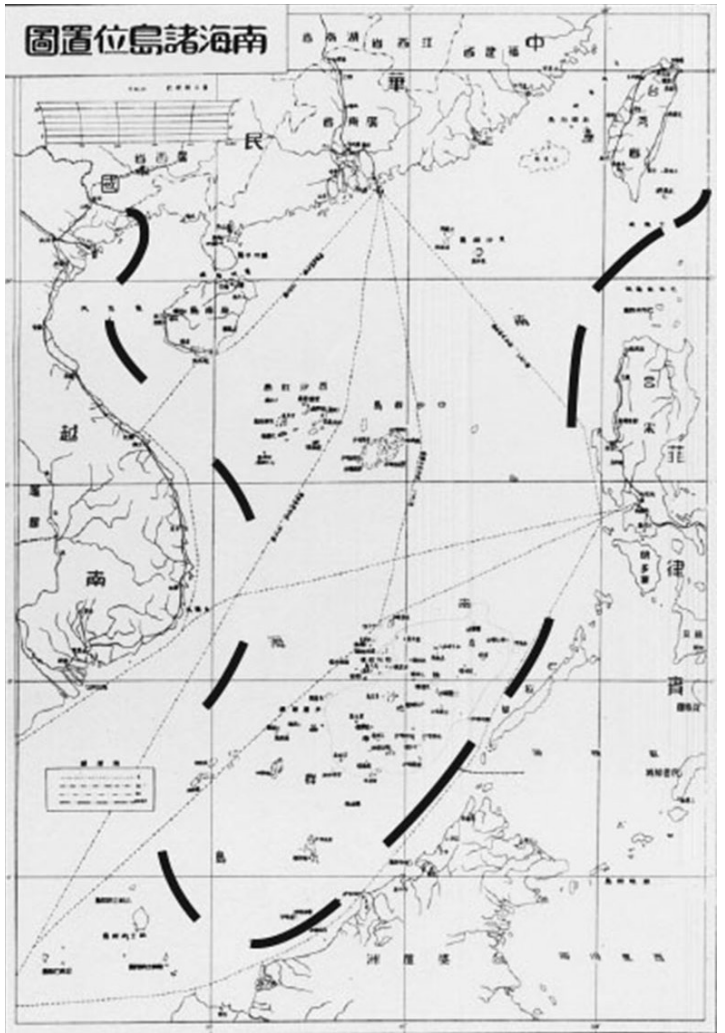

This line is thus commonly referred to as the 'U-shaped line.' The 1948 map served an administrative purpose, illustrating China's territorial claims in the SCS. According to Chinese analysts, when the 1947 map was published, no other State had logged a diplomatic protest. ${ }^{33}$ This is argued to be an "act of acquiescence" ${ }^{34}$ with respect to

32 See Chinese Official Map, available at http://imageshack.us/f/848/1947nanhaizhudao.png (last visited on Mar. 25, 2013).

33 Z. Guocai, Cong xianxing haiyangfa fenxi nanshaqundao de zhuquan zhengduan (Analysis of the Sovereign Dispute over the Spratlys under the Present Law of Sea), 9 Asian Rev. 22 (1999), recited from L. Jinming \& L. Dexia, The Dotted Line on the Chinese Map of the South China Sea: A Note, 34 OcEan Dev. \& INT'L L. 292 (2003).

34 Acquiescence is a established principle in customary international law, which designates the failure by other interested States in lodging into an effective protest in response to the action taken by the former constitutes a formal recognition of the claims and the legality of the claims can thus be justified by such non-actions (protests, objections, etc.). For details on 'acquiescence,' see P. Chan, Acquiescence/Estoppel in International Boundaries: Temple of Preah Vihear Revisited, 3 ChINESE J. INT'L L. 422 (2004). 'Acquiescence' is a concept tacitly conveyed by a state unilaterally, through silence or inaction, in circumstances such that response expressing disagreement or objection in relation to the conduct of another State would be called for. Acquiescence is thus consent inferred from a juridically relevant silence 
China's sovereignty claim in the SCS. However, other claimant countries have made counter arguments noting that, still under colonial rule at the time, they had no political power to officially challenge the Chinese position. ${ }^{35}$ Thus, their inaction does not imply acquiescence to Chinese claims. Moreover, principles of international law, such as discovery, proximity, and effective control are simultaneously applicable to all the disputant countries in the claims. In any case, with regard to Chinese claims, the PRC later inherited the dotted lines after 1949. In 1953, however, the late Premier Zhou En-lai decided to drop the two lines in the Tonkin Gulf; Chinese maps published ever since show only nine dotted lines instead of eleven. ${ }^{36}$ (Figure 3) At present, China occupies eight of the Paracel Islands, a large Spratly Islands group, and several reefs in the Spratly Islands.

Figure 3: China's Official Nine Dashed Lines in the South China Sea ${ }^{37}$

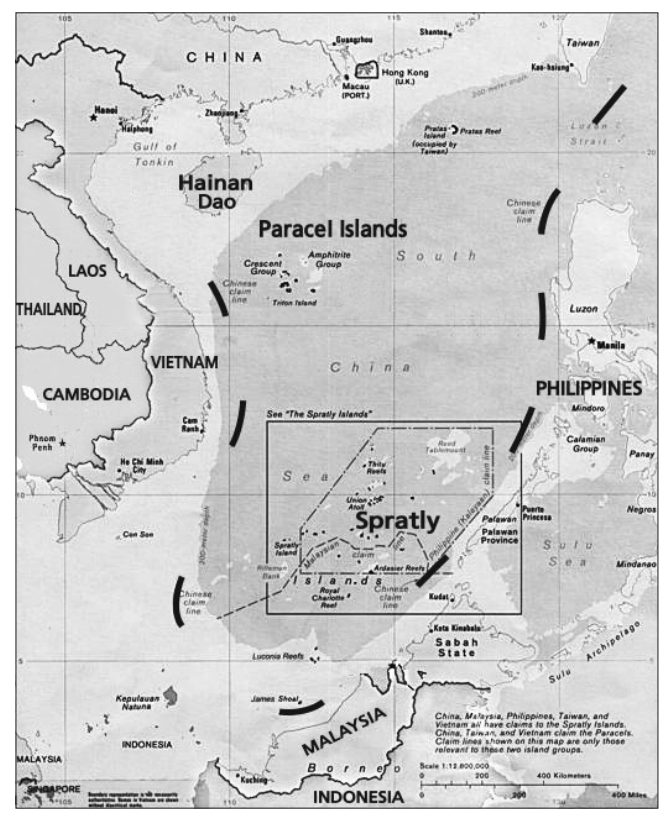

or inaction. See Max Planck Encyclopedia of International Law, available at http://www.mpepil.com/subscriber_ article?script=yes\&id=/epil/entries/law-9780199231690-e1373\&recno=3\&subject=Sources, \%20foundations $\% 20$ and $\% 20$ principles $\% 20$ of $\% 20$ international $\% 20$ law (last visited on Apr. 12, 2013).

35 Supra note 25 at 54 (n. 14).

36 Id. at 54.

37 D. Lague, China's Official Nine Dashed Line, ChIna DaILy MaIL, May 25, 2012, available at http://chinadailymail. com/2012/05/25/chinas-nine-dashed-line-in-south-china-sea, recited from Communication from China to the United Nations, May 7, 2009, available at http://www.un.org/Depts/los/clcs_new/submissions_files/submission_ vnm_37_2009.htm (all last visited on Mar. 25, 2013). 
China is the most dominant power in the region. Its bold actions regarding sovereignty claims over the SCS have caused some concerns for its neighboring countries, as their claims are undermined by China's position. Although the implications of the U-shaped line drawn by China are unclear in international law, China's claim of sovereignty around this U-shaped line is based on so-called 'historical rights.' China would suggest that such rights pre-date the time when provisions of UNCLOS have come into place. ${ }^{38}$ Thus, this new development did not negate China's prior rights over the SCS. Moreover, in 1992, two years before UNCLOS came into force, China passed a law reasserting its right over the SCS. ${ }^{39}$ Today, China takes a clear stance on the fact that its claims are based on both UNCLOS - as it is a party to the Convention - and its historical rights within the U-shaped line. ${ }^{40}$

\section{B. Other Coastal States' Positions}

\section{Taiwan}

Taiwan has based its claims on the same historical legitimization used by the PRC. Taiwan maintains identical claims as those of China. It is due to the fact that in 1947, the Nationalist government of the Republic of China (as of today, Taiwan), which was at that time in control of mainland China, began to publish maps with U-shaped lines in the SCS delineating its maritime boundaries. These maps were based on a 1935 internal government report prepared to define the limits of China, even though many parts of which were dominated by outside powers at that time. The PRC's Department of Defense has confirmed that beginning in the 1930s and 1940s, the Republic of China began publishing regional maps with dashed lines around the perimeter of the SCS. After taking power in 1949, the Chinese Communist Party ("CCP") continues to maintain this claim. Both the PRC and Taiwan continue to base their SCS claims on that broad delineation. Today both China and Taiwan claim nine dashed U-shaped lines as their maritime boundaries in the SCS, as neither of the countries has given up sovereignty claims over each other's territories. ${ }^{41}$

\footnotetext{
L. Buszynski, The South China Sea: Oil, Maritime Claims, and U.S.-China Strategic Rivalry, WASH. Q. 140 (2012).

Burgess, supra note 1 , at 8.

Supra note 25, at 54.

41 See R. O'Rourke, Maritime Territorial and Exclusive Economic Zone (EEZ) Disputes Involving China: Issues for Congress, CRS Report to Congress, 11 (n. 16) (2011), Dec. 10, 2012, available at http://www.fas.org/sgp/crs/row/ R42784.pdf (last visited on Apr. 12, 2013). See also P. Dutton, Three Disputes and Three Objectives China and South China Sea, 64 Naval War College Rev. 44-45 (2011). On the status of sovereignty claims of each other's territories, see the UN General Assembly Fourth Committee (“SPECPOL”) Study Guide, Mumbain Mun 4 (2013), available at http://www.mumbaimun.com/resources/study-guides/specpol2.pdf (last visited Apr. 12, 2013).
} 


\section{Vietnam}

The claims of Vietnam, similar to those of China, are based on both historical and archaeological arguments, especially regarding the Spratly Islands. ${ }^{42}$ Historical evidence is revealed by occupations conducted by France, the then colonial authority in Vietnam. Thus, Vietnam has argued that it inherited rights as a successor State and claims an extensive area of the SCS, including all of the Spratly Islands. ${ }^{43}$ At present, Vietnam occupies 23 of the Spratly Islands, more than any other States. ${ }^{44}$ In addition, the regime of South Vietnam had also occupied the Paracel Island groups until the PRC took them back by force in $1976 .{ }^{45}$

\section{The Philippines}

The Philippines both occupies and lays claims to many of the Spratly Islands, based on a quasi-judicial notion of 'proximity' through reference to the alleged discovery of the islands by Filipino explorers in $1956 .{ }^{46}$ The Philippines also regarded the Spratly Islands as terra nullius until 1947. However, the discovery of the islands by Tomas Cloma, a Filipino lawyer and businessman, led the Philippines to claim rights over the islands in 1947, based on the principle of effective discovery. Today, the Philippines occupies eight islands, referred to as the Kalayaan Islands group, which were made a part of Palawan Province under a presidential decree in 1972. ${ }^{47}$

\section{Malaysia}

Malaysia claims three islands of the southern Spratlys, grounding its claim on both occupation and geographical proximity founded on the continental shelf principle. Malaysia argues that these islands lie within the prolongation of its continental shelf and bases its claim to these three islands on Article 76 of UNCLOS. ${ }^{48}$ It has established a garrison on Layang Layang Island, the largest of the three islands, which it has occupied since 1983. It has also successfully developed Swallow Reef into a resort. ${ }^{49}$ Lastly, it has been reported that Malaysia has constructed several

42 Vietnam claims all of both the Spratly and Paracel island chains. See Hong Thao Nguyen, Vietnam's Position on the Sovereignty over the Pracels \& the Spratlys: Its Maritime Claims, 5 J. EASt AsIA \& INT'L L. 165-211 (2011); MinISTRY of Foreign Affairs of Vietnam, The Hoang Sa and Truong Sa Archipelagoes Vietnamese Territories (1981).

43 Nguyen, $i d$. at 168.

44 Bautista, supra note 1, at 714.

45 Supra note 6, at 96.

46 Burgess, supra note 1 , at 8 .

47 Id. at 715.

48 UNCLOS art. 76 (1).

49 Bautista, supra note 1, at 715-716. 
structures on the features that it claims, such as on Erica Reef. ${ }^{50}$

\section{Brunei}

Although Brunei occupies none of the islands, it claims a large maritime zone running through the Spratly Islands. ${ }^{51}$ In 1984, it declared an EEZ that includes the Louisa Reef, which had also been claimed by Malaysia. As a result, these two countries have been engaged in negotiations since then. ${ }^{52}$ Today, Brunei is the only State not to have established a military presence on at least one of the islands. Similar to Brunei, Indonesia does not claim any of the contested islands. It does, however, have an overlapping claim to a maritime zone with Vietnam and China. ${ }^{53}$ The six primary nations that share a role in the disputes have based their claims on principles of general international law, and particularly the provisions of UNCLOS.

Although developments after 1994 included military and diplomatic tensions regarding the claims, particularly on those located within the Spratly Islands group, ${ }^{54}$ there have been some engagements by the Association of Southeast Asian Nations ("ASEAN") to peacefully settle the disputes. The States involved in the disputes have all alleged that their territorial claims are fully supported by international law in general and UNCLOS in particular. ${ }^{55}$

\section{The US Policy in the SCS}

\section{A. A Basic US Position}

Given the fact that the overall US national interests in the Asia-Pacific region are in one way or another linked to the SCS, the US concerns in the region lie in legal, political, military, and geostrategic spheres. Because of China's potential rise as a

\footnotetext{
Supra note 6, at 101.

1 Burgess, supra note 1 , at 8.

52 Bautista, supra note 1 , at 716.

53 Burgess, supra note 1 , at 8.

54 In 1995, e.g., military confrontation took place between China and the Philippines when Filipino forces dispatched ten aircraft and three patrol boats near the Mischief Reef area where the Chinese fishery administration was constructing shelters for Chinese fishermen who habitually engage in fishing production there. China has also strongly and persistently protested both military and non-military actions undertaken particularly by Vietnam, the Philippines and Malaysia in the SCS. See supra note 6, at 100.

55 Burgess, supra note 1 , at 9.
} 
hegemonic power, the US has adopted a policy of "containment, ${ }^{56}$ with a view to at least delaying China's rise in order to preserve its own dominance. While this containment policy has been a point of issue in the US policy debate as to how to respond to China's great power aspiration, the fact is that the latter's influence in the global agenda, as well as in the regional politics, pushes the US to re-think the overall calculation. ${ }^{57}$ However, the US engagement in the SCS is directed at a power balance by way of protecting its own interests as well as those of its allies in the region. While the complex set of territorial claims does not apparently involve the US in the disputes, its concern is that its general interests in the region as a whole are expected to be affected unless a peaceful settlement is pursued. The US engagement in the disputes, therefore, would largely facilitate the settlement process and ensure its legitimate interests in the SCS.

Up until the mid-1990s, the official US stance was "not to take any position" in the disputes. ${ }^{58}$ In the wake of the 1974 Paracel Islands clash, e.g., the US State Department clearly articulated that the disputes were to be settled among the claimants themselves. ${ }^{59}$ Thus, the 1974 takeover of the islands by China was fairly safe, mainly because this took place at a time when the US was hoping to obtain some degree of Chinese cooperation over its disengagement from Vietnam. ${ }^{60}$ Similarly, the US barely reacted to the Chinese use of force in establishing its presence in the Spratly

56 J. Lingfei, Meiguo Duihua Ezhi Zhanlue de Zhiyue Yinsu he Keneng Zouxiang (Factors behind US containment strategy against China and its possible orientation), 5 STRATEGY AND MANAGEMENT 46-50 (1996), recited from Y. Bin, Containment by Stealth: Chinese Views of and Policies toward America's Alliances with Japan and Korea after the Cold War (1999), available at http://iis-db.stanford.edu/pubs/10029/YuBin_final_PM.pdf (last visited on Apr. 6, 2013). For details on 'containment,' see G. Kennan, The Sources of Soviet Conduct, 25 ForeIGN AfF. 566-582 (July 1947).

57 U. Granados, United States' New Leverage in the South China Sea? Current Trends amid a New Asia-Pacific Strategy, in EAST Asia Security Symposium and Conference (J. Ping ed. 2012), available at $\mathrm{http}$ ://epublications.bond.edu.au/eassc_publications (last visited on Apr. 6, 2013).

58 C. Shelly, Acting Spokesperson of U.S. Department of State, "Spratlys and the South China Sea," May 10, 1995, recited from R. Emmers, The De-escalation of the Spratly Dispute in Sino-Southeast Asian Relations, S. Rajaratnam School of International Studies, 129 WorkIng PAPER 17 (Jun. 6, 2007) available at http://www.rsis.edu.sg/publications/WorkingPapers/WP129.pdf (last visited Apr. 12, 2013). It states:

The United States takes no position on the legal merits of the competing claims to sovereignty over the various islands, reefs, atolls and cays in the South China Sea. The United States would, however, view with serious concern any maritime claim, or restriction on maritime activity, in the South China Sea that was not consistent with international law, including the 1982 United Nations Convention on the Law of the Sea.

See also R. Cossa, Security Implications of Conflict in the South China Sea: Exploring Potential Triggers of Conflict, A Pacific Forum CSIS Special Report, app. G. (1998), available at http://www.southchinasea.org/files/2012/03/CossaSecurity-Implications-of-Conflict-in-the-S.ChinaSea.pdf (last visited on Apr. 6, 2013).

59 Supra note 3, at 112. See also M. Morrow, Today Hsisha, Tomorrow ...? FAR EAstern Econ. Rev. 32 (Jan. 28, 1974).

60 L. To, China, the USA and the South China Sea Conflicts, 34 Security Dialogue 28 (2003). 
Islands in $1988 .^{61}$ In regard to the US-Philippines Mutual Defense Treaty of $1951,{ }^{62}$ Washington clarified that the treaty did not automatically cover the Spratly Islands, as they were disputed territories and had not been claimed by Manila until the treaty was signed. ${ }^{63}$ For this reason, the US did not invoke the treaty even after China encroached into the uninhabited Mischief Reef in $1995,{ }^{64}$ on which the Philippines claims sovereignty. Until then, the US had clearly remained neutral. ${ }^{65}$ At that time, the US strategy was to counter Soviet influence in the region by placing China as it was considered a strategic partner of the US to safeguard its interests in the region. ${ }^{66}$ However, the US declared that it would have a fundamental interest in the SCS, and that any restriction (imposed by the claimants) on the freedom of navigation and on other associated maritime activities should be consistent with international law. ${ }^{67}$ Nevertheless, on the other side, the US constantly refused to take part in the SCS disputes over sovereignty claims. Instead, it put importance first on the Indonesialed initiative and then on the ASEAN Regional Forum ("ARF")-led initiative in the settlement of the disputes. ${ }^{6}$

It was not until 1994 that the US position shifted from passive to active. At that time, UNCLOS entered into force in 1994 and Chinese military surveillance over the SCS increased. ${ }^{69}$ This change was mainly due to a weakened Soviet threat and China's rapid growth in economic and military capability. Since the mid-1990s, strategic security has been a key to understanding the US policy in the SCS. ${ }^{70}$ China's growing naval capacity and increased surveillance, as well as its control over the SCS, leave both the US and its regional allies (the ASEAN countries) with larger concerns. These concerns have been exacerbated by China's reasserting its sovereignty claims in the SCS, ${ }^{71}$ directly or indirectly threatening the US interests.

$61 \quad I d$.

62 See the full text of the US-Philippine Mutual Defense Treaty, available at http://www.chanrobles.com/ mutualdefensetreaty.htm (last visited on Apr. 6, 2013).

63 Cossa, supra note 58, at 5. See also supra note 3, at 114.

64 Cossa, id. at 5.

65 Two years after the first Mischief Reef incident, the US-Philippine Visiting Forces Agreement ("VFA") was signed on February 10, 1998. See A. Guan, The South China Sea Dispute Re-visited, 4 Working Paper Series 12 (Institute of Defence and Strategic Studies, 1999), available at http://www.rsis.edu.sg/publications/WorkingPapers/WP04.pdf (last visited on Apr. 6, 2013).

66 Supra note 3 at 113.

67 Id. at 114.

68 Supra note 60, at 32-33.

69 R. Drifte, Japan's Security Relations with China Since 1989 From Balancing to Bandwagoning 63 (2003).

70 W. Lohman, Strong American Priorities in the South China Sea, 3297 WebMemo, The Heritage Foundation, Jun. 20, 2011, available at $\mathrm{http} / /$ thf_media.s3.amazonaws.com/2011/pdf/wm3297.pdf (last visited on Apr. 6, 2013).

71 Supra note 23, at 27. 
The US clearly opposed any use or threat of force to resolve competing claims. ${ }^{72}$ It also urged all claimant countries to exercise restraint and to avoid actions that would destabilize the region, stressing an abiding interest in the maintenance of peace and stability in the SCS. ${ }^{73}$ Furthermore, Washington reiterated that freedom of navigation and all maritime activities consistent with international law is America's priority in the region. ${ }^{74}$ Finally, the US reconfirmed to take 'no position' on the legal merits of the competing claims to sovereignty over the various islands, reefs, atolls, and cays in the SCS. ${ }^{75}$ However, the continuous expansion of Chinese structures on Mischief Reef in late 1998, as well as the counteractions, propelled the US to express serious concerns. At the 1999 ARF the then Secretary of State, Madeleine Albright, stated that the US simply could not sit on the sidelines and watch these disputes. ${ }^{76}$ The USPhilippines security alliance, which was eventually transformed by the endorsement of the Visiting Forces Agreement ("VFA") of 1999, has arguably been added to this new development. This agreement allows the US to resume normal military-tomilitary contact with the Philippines, including warship visits and joint military exercises. This development is likely justified by Madeleine Albright's statement at the 1999 ARF. ${ }^{77}$ It finally noted that the US would not sit on the sidelines in the event of a conflict that could jeopardize its interests in the region.

\section{B. Significance of the SCS for the US}

\section{Trades and Investment}

The significant economic and business interests of the US in the region lie in ensuring its right to navigation through the SCS. Ninety percent of the oil destined for its allies passes through the SCS and the Strait of Malacca. ${ }^{78}$ In addition, its strategic allies share vital interests in the SCS. Japanese tankers, e.g., carry $70 \%$ of their oil on sea lanes of the SCS. ${ }^{79}$ Overall, oil flow through the Strait of Malacca is

72 Supra note 58. See also A. Espina, Recent Development in the South China Sea and Prospects for Joint Development, RCAPS Working Paper Series "Dojo" 24 (RITSUMEIKAN AsIa PACIFIC UnIVERsity, 2012), available at http://www.apu.ac.jp/rcaps/uploads/fckeditor/publications/workingPapers/RCAPS_RPD-12001.pdf (last visited on Apr. 12, 2013).

73 Espina, id.

74 Supra note 58.

75 Id.

76 Supra note 60 , at 35 .

77 As a matter of fact, in February 2000, the US and the Philippines held their first large-scale joint exercise since 1993 involving more than 2,500 US military personnel. See generally id. at 31 .

78 Supra note 3, at 110.

79 Id. at 109. 
3 times greater than that of the Suez Canal and 15 times greater than the oil flow through the Panama Canal. ${ }^{80}$ Today, more than 50,000 vessels pass through roughly 1,000 kilometers of the Strait of Malacca each year, which is around one-third of the tonnage of world shipping. ${ }^{81}$ The US trade in the Asia-Pacific region, for which the SCS serves as the main channel, is already larger than that of Europe. ${ }^{82}$ Currently, US-Southeast Asian trade amounts to over USD200 billion annually, with the US investment in the region at over USD100 billion. ${ }^{83}$

\section{Resources}

The resource potential of the SCS is another important factor. The SCS is estimated to have a large amount of oil and gas reserves. The study conducted by the United States Geological Survey (“USGS") in 2010 suggested that the estimate may contain anywhere between 5 and 22 billion barrels of oil and between 70 and 290 trillion cubic feet of gas in as-yet undiscovered resources. ${ }^{84}$ The undiscovered resources could be even greater, as the USGS assessment had not examined the entire area. ${ }^{85}$ These resources may be the most important attraction for China, as its energy demands are rapidly growing. The SCS is regarded as one of China's ten most important strategic oil and gas sources. ${ }^{86}$ In and around the Spratly Islands area, China has been unable to set up an oil platform, let alone the production of oil. Even though some of the disputing States in the SCS have set up more than 1,000 wells in the SCS, the amount that they have produced as a result of these projects has been several times higher than China's production in offshore areas. ${ }^{87}$ The US has interests in terms of both energy imports from the region, and maintenance of the interests of its companies involved in the regional hydrocarbon development. These dual interests are linked to maintaining a stable legal order in the SCS among the regional actors, many of which are significant strategic and commercial partners of the US.

80 H.-D. Evers \& S. Gerke, The Strategic Importance of the Straits of Malacca for World Trade and Regional Development, 17 ZEF Working Paper Series 7 (University of Bonn, 2006), available at http://www.uni-bonn. de/ hevers/papers/WP17_Evers-Gerke.pdf(last visited on Apr. 6, 2013).

81 Id.

82 Supra note 3 at 110.

83 R. Cronin, China's Activities in Southeast Asia and the Implications for U.S. Interests, Hearing before US-China Economic and Security Review Commission, Feb. 4, 2010, available at $\mathrm{http}: / /$ origin.www.uscc.gov/sites/default/files/tr anscripts/2.4.10HearingTranscript.pdf (last visited on Apr. 6, 2013).

84 See South China Sea, US Energy Information Administration, Feb. 7, 2013, available at http://www.eia.gov/countries/ analysisbriefs/South_China_Sea/south_china_sea.pdf(last visited on Apr. 6, 2013).

85 Id.

86 Supra note 25, at 51.

87 Id. 
American companies are already engaged in numerous drilling projects in the SCS. ${ }^{88}$ China puts pressure on international energy companies, such as Exxon Mobile and British Petroleum, not to work in oil and gas exploration in areas off Vietnam's coast, which China considers to be its EEZ. ${ }^{89}$ In addition, China's dispatch of Fisheries Administration Patrol Vessels to "protect its sea areas" ${ }^{90}$ provided reasons for the US to be concerned that its economic interests, especially concerning hydrocarbon resources, might be vulnerable. Potential hydrocarbon reserves, especially in and around the Spratly Islands, and Chinese efforts to nationalize these resources in recent decades have emerged as a signal for resource confrontation affecting the US economic interests tied to its regional allies. ${ }^{91}$ The US also incurs an obligation for protecting the interests of its oil companies involved in hydrocarbon development. ${ }^{92}$

\section{Strategic Cooperation}

As one of the main strategic paths in the world, the SCS will arguably remain the object of great power struggles in the future. In the "new-Cold War" era of global security concerns, the regional presence of the US is argued to be based on strategic interests. ${ }^{93}$ The decrease of its influence in the region will create a power vacuum that is likely to be filled by China. ${ }^{94}$ Given the fact that maintenance of peace and stability in the region is the ultimate priority of the US in the pursuit of its interests, its presence in the region seems crucial. The continued engagement within the region allows the US to shape future prospects. Moreover, it has legal obligations towards the Philippines, one of the six claimant States in the SCS, to act in response to an attack against the latter's territory. The 1951 US-Philippines Mutual Defense Treaty obliges the US to "act to meet the common dangers" in an attack on the territory of the Philippines or "its armed forces, public vessels or aircraft in the Pacific." 95 Although the security cooperation was largely suspended in the 1990s, a renewed initiative emerged in 1999 with the ratification of the VFA between the US and the Philippines. This VFA allows US war ships' visits and some joint military exercises. The first joint large-scale exercise since 1993 was performed in 2000 under

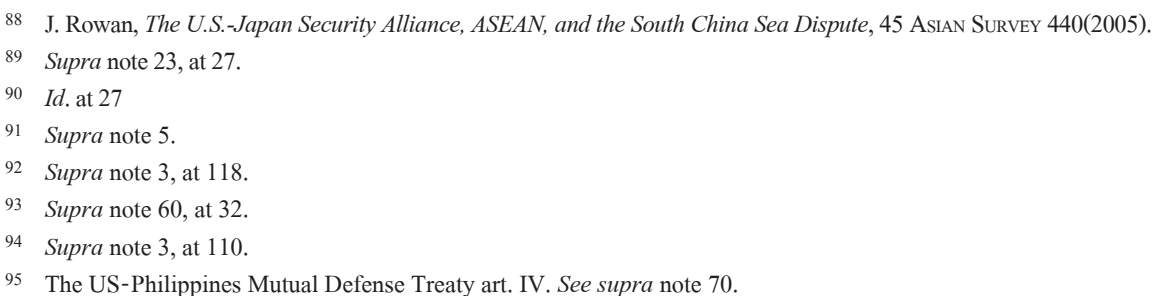


the VFA, which involved more than 2,500 US military personnel. ${ }^{96}$

\section{Post-September 11}

After the September 11 incident, the global war on terror, initiated under the Bush Administration, developed a new strategy known as "pre-emptive self-defense." 97 It has potential implications for the strategic presence of the US in the SCS. Under this development, the US perceives the right to act in a pre-emptive manner that is motivated by its own unilateral judgment. The global role of the US has fundamentally emerged via strengthening its military and security structures in collaboration with its allies. Evidently, the SCS is considered to be a key region for the US security concerns. The Bush Administration labelled Southeast Asia as the 'second front' in the war on terror. ${ }^{98}$ While China has seemingly supported the US-led war on terror, it remains critical of the American policy of increasing its global military presence, particularly in the SCS. ${ }^{99}$ Nevertheless, since the September 11 attacks, the US has gradually increased its intelligence and military cooperation with the allies in the SCS. ${ }^{100}$ In the case of the Philippines, e.g., the US has begun to hold joint operations against the Al Qaeda-linked Abu Sayyaf. ${ }^{101}$ The VFA has proven to be a perfect platform for the initiation of joint operations. ${ }^{102}$ Additionally, the US has undertaken various other cooperative arrangements with the SCS actors in order to enhance its national security interests. ${ }^{103}$ The ASEAN-United States Joint Declaration to Combat International Terrorism, ${ }^{104}$ signed in Bandar Seri Begawan in August 2002, is particularly interesting, as it confirms the US security interests in the SCS as one of its top priorities.

96 Supra note 60 , at 31

97 Supra note 2.

98 E. Economy, China's Rise in Southeast Asia: implication for the United States, 14 J. Contemporary China 418 (2005).

99 Supra note 60, at 27.

$100 I d$. at 28.

101 Id. at 31 .

102 The US military assistance to the Philippines is remarkable. In 2005, the US military financing assistance to the Philippines was 30 million dollar, the amount that is 17 million dollar more than that of the previous year. See supra note 98 , at 419 .

103 Despite Malaysia's rejection in the first place, it has eventually been engaged in a series of training exercises with the US naval forces. The following countries took part in the similar exercises as: Brunei, Thailand, Indonesia, Singapore and the Philippines. China has participated as an observer in some of these exercises. Id. at 419.

104 See the full text of the Declaration, available at http://www.aseansec.org/7424.htm (last visited on Apr. 6, 2013). 


\section{US-China Relations over the SCS in the Context of UNCLOS}

\section{A. Current Hegemonic Competition between the US and China}

The US and China recognize themselves as 'strategic partners.' Their relations contain elements of both rivalry and cooperation. ${ }^{105}$ Consequently, both international law and diplomacy play major roles in untangling disputes over the issues concerning the SCS. ${ }^{106}$ The US views that its legal interests concerning freedom of navigation under the law of the sea are being jeopardized by China's claim on so-called 'historic rights' in and around the U-shaped line. However, China does not understand that the engagement of the US in the SCS is merely to ensure the freedom of navigation under international law. ${ }^{107}$ Rather, China believes that the ultimate goal of the US engagement in the disputes is to expand its hegemonic influence to the region. ${ }^{108}$ For China, the US being a non-party to these regional territorial disputes has no legal standing; on the other hand, the US views that its legal interests in the SCS are affected by the disputes among the nations in the region, many of which are its allies.

Over the last decades, China has already established itself as a regional power in and around the SCS. Being the largest claimant State that is directly involved in the disputes with considerable influence on the development and outcome of any potential 'flashpoint,' ${ }^{, 109}$ China regards the SCS as a 'core interest. ${ }^{, 110}$ Both heightened energy demands and security concerns are the major reasons behind this idea. The shift in geopolitical dynamics has led China to put a strong emphasis on its national security concerns in the region. China has rapidly strengthened its national security with the growth of its economic and military capacity. ${ }^{111}$ Over the past decade, China has also made efforts to enhance its maritime enforcement capabilities, including

\footnotetext{
105 Thayer, supra note 18 , at 70.

106 M. Valencia, China and the South China Sea Disputes 27 (1995).

107 Supra note 3, at 107-108.

108 Id.

109 Supra note 60, at 25 .

110 Thayer, supra note 18 , at 69.

111 China's defense spending has increased more than five hundred percent, in real terms, since 1997. Despite its overwhelming economic development, defense expenditure (11-15 percent) has exceeded economic growth (8-9 percent). Id. at 70. See also R. Hsiao, In a Fortnight PLAN East Sea Fleet Moves Beyond First Island Chain, X(9) China Brief: A Journal of Analysis and Information 1 (2010). China's People Liberation Army Navy carried out a series of unprecedented exercises far from China's coastal waters in the Yellow Sea and the East Sea of Korea. See Thayer, supra note 18 , at 70 .
} 
the development of 'unprecedented capability' to use satellites in monitoring and conducting operations along its disputed maritime periphery. ${ }^{112}$ China's military build-up in the SCS, along with its potential for provocative actions, carries huge implications for the US. In addition, China's economic growth apparently intensifies its energy demands in a dramatic manner, which leaves the US with the concern that China would behave adamantly in establishing its territorial claims over islands located in the SCS. ${ }^{113}$ The consequence on the part of China then might be restraining the "freedom of navigation" of the other States based on the 'historic rights' argument. ${ }^{114}$ In the event of China's rise in global power politics and of the dynamics of a new world order, the US is concerned about its legal rights and pertinent interests, as well as its geopolitical influence in the SCS. After the September 11 incident, the national security policy of the US has been explicitly directed to prevent the emergence of future competitors ${ }^{115}$ and to establish its own primacy in the SCS over China's emergence. ${ }^{116}$ In 2010, the US Department of Defense reiterated its commitment to remain present and postured as the pre-emptive military force in the region by both "word and deed." 117 It hinted at the likelihood of the show of military force and action in cases where its interests, particularly regarding the freedom of navigation, are restrained. ${ }^{118}$

China regards the US attitude, continuous involvement, and push for a multilateral solution involving the ARF in the SCS as 'interference.' It is also accusing the US of encouraging the Southeast Asian nations to form a 'united front' against China. With regard to the SCS, ${ }^{119}$ it maintains that, in the future, the SCS issue will influence competition between these two superpowers - for both its potential energy resources and value as a strategic path, especially through the Strait of Malacca. ${ }^{120}$ However, despite China's reluctance toward multilateral engagement in the SCS, it signed an instrument, the ASEAN-China Declaration of Conduct of Parties in the SCS in 2002. ${ }^{121}$ The declaration only asserts "self-restraint in the conduct of activities

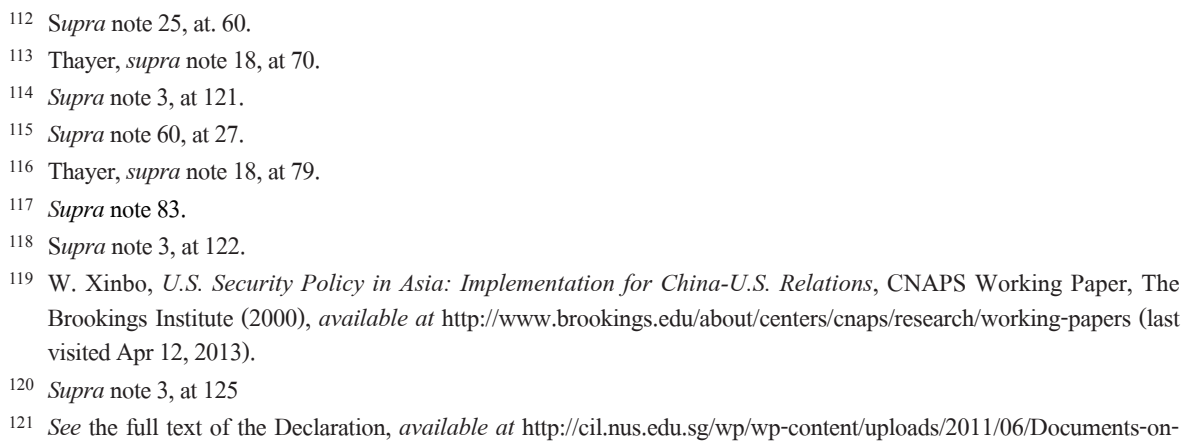


that would complicate or escalate disputes. ${ }^{122}$ For China, however, it has served as a major shift in engaging other disputants on a multilateral basis. ${ }^{123}$ Nevertheless, China has not moved away from its principle of emphasizing a bilateral approach in such an engagement. ${ }^{124}$ China has consistently pointed out that, when it comes to problems concerning territory and sovereignty, only countries involved in the controversies should be allowed to solve disputes via bilateral negotiations, ${ }^{125}$ leaving out any third-party engagement.

\section{B. The US-China Relations in the SCS under UNCLOS}

Apart from the legality of the 'historic title' claim within the U-shaped line, three sections of UNCLOS are most relevant, as far as territorial sovereignty claims in the SCS are concerned. These three sections deal with issues regarding maritime boundaries such as territorial sea, the EEZs and continental shelf. In the waters beyond the territorial sea, non-coastal States enjoy a legitimate right of navigation, as well as certain other rights. Precise rules regarding these issues are found in Articles 3, 55-75, and 76-77 of UNCLOS, respectively. In the case of the SCS, establishing maritime zones in accordance with the provisions of the law of the sea depends on the dissolution of the question on the right of valid title over the disputed islands, ${ }^{126}$ which is of great complexity, as discussed above. This section only shows the dynamics of China-US relations within the framework of the law of the sea that are available in the SCS disputes. It specifically analyzes tensions between China and the US over issues concerning jurisdictional rights within the U-shaped line, 'rock' questions and the right to freedom of navigation.

Although China is a party to UNCLOS, which is committed to the provisions of the law of the sea, it nevertheless claims its rights in the SCS under the "historic rights' concept, as well. What exactly this 'historic rights' means is ambiguous. However, there are several different interpretations. The moot point of these interpretations is in and around China's U-shaped line. Some view the map as

ASEAN-and-South-China-Sea-as-of-June-2011.pdf (last visited on Apr. 6, 2013). For details, see Yann-Huei Song, The Declaration on the Conduct of Parties and a Code of Conduct in the South China Sea: Recent Actions Taken by ASEAN, 52 AsIA PACIFIC STUdIES (亞太研究論壇) (2011)

122 Thayer, supra note 18 , at 83 . See also supra note 25 , at 55.

123 Id.

124 Supra note 60, at 29.

125 Id. at 30.

126 G. Triggs, Maritime Boundary Disputes in the South China Sea: International Legal Issues, 09/37 University of Sydney Law School Legal Studies Research Paper 4 (2009), available at http://papers.ssrn.com/sol3/papers.cfm?abstract id=1401189 (last visited on Apr. 10, 2013). 
representing only the enclosed islands, ${ }^{127}$ while the others assert sovereign rights also over the waters within the line. ${ }^{128} \mathrm{~A}$ third group argues for a historic title over the waters. ${ }^{129}$ The most dominant view among the scholars, however, suggests that the nine-dotted mark around the U-shaped line merely represents China's claims on the islands in the SCS and maritime rights surrounding the waters thereof. ${ }^{130}$ China, in its official documents, apparently has never claimed an ownership right over the entire water column of the SCS. ${ }^{131}$ Even in its recent document submitted to the Commission on the Limits of the Continental Shelf ("CLCS"), China has not explicitly asserted its claim of 'historic rights' over the water body. ${ }^{132}$

However, a claim of historic rights over the entire water body also demands legal analysis. Unfortunately, neither the Territorial Sea Convention of 1958, nor UNCLOS was explicit on the question of historic rights. Yet, the legal basis of the concept of 'historic title' is not unfamiliar in the law of the sea, since Article 15 of UNCLOS recognizes the existence of the concept, despite its ambiguity in international law. ${ }^{133}$ The concept can nonetheless be analyzed from the viewpoint of customary law. It is argued that to successfully assert a claim to historic title over waters, three factors are indispensable: (a) States which claim historic title should exercise sovereignty in the waters; (b) the exercise of sovereignty should have been continuous for a long time and should have become the usage; and (c) it should be tolerated by other States. $^{134}$

China's historic right over the waters within the U-shaped line has to be analyzed based on the three above-mentioned factors. Although it has been argued that China, since the announcement of the dotted line in 1947, has been repeatedly claiming sovereignty over the SCS, the historic right argument has never been made

127 G. Zhiguo, The South China Sea: From Conflict to Cooperation, 25 OcEan Dev. \& InT'L L. 346 (1994).

128 Jinming \& Dexia, supra note 33, at 291.

129 Z. Lihai, Haiyang fa wenti yanju (Studies on the Law of SEA) 37 (Beijing University, 1996), recited from Jinming \& Dexia, supra note 33, at 291.

130 G. Zhiguo, The South China Sea: From Conflict to Cooperation, 25 OcEan Dev. \& InT'L L. 346 (1994). For details on the China's claims around nine dotted line, see Jinming \& Dexia, supra note 33, at 291-292.

131 Zhiguo, id. at 346. See also Zou Keyuan, The Chinese Traditional Maritime Boundary Line in the South China Sea and Its Legal Consequences for the Resolution of the Dispute over the Spratly Islands, 14 InT’L J. MARINE \& COASTAL L. 52 (1997).

132 In 2009, in response to joint Vietnamese and Malaysian submission of extended continental shelf claims to the CLCS, as well as that of a separate submission by Vietnam, China objected via a note of verbale without making any formal submission by itself. See The note of verbale, available at $\mathrm{http} / /$ www.un.org/depts/los/clcs_new/submissions_files/ mysvnm33_09/chn_2009re_mys_vnm_e.pdf (last visited on Apr. 6, 2013).

133 It stipulates that the median line of delimitation "does not apply ... where it is necessary by reason of historic title or other special circumstances to delimit the territorial seas of the two States in a way which is at variance with this provision."

134 Jinming \& Dexia, supra note 33, at 292. 
explicitly clear. To have a successful claim over the waters, historic waters must have been treated as internal or territorial areas to which a coastal State would have exclusive jurisdiction. ${ }^{135}$ It is argued that China has only occasionally practiced exclusive rights over the islands around the U-shaped line, but not on waters within the line. ${ }^{136}$ Historically, the waters in the SCS have always been free for foreign vessels to navigate as well as to fish without control in waters within the line. ${ }^{137}$ Moreover, the Exclusive Economic Zone and Continental Shelf Act of the People's Republic of China of 1998, in its Article 14, stipulates that the provision of the law would not affect China's claim of historic rights. The assertion brings confusion as far as historic rights do not contain waters in the EEZ or continental shelf. ${ }^{138}$ It is therefore manifested that China's claim of historic rights does not extend to waters in the SCS, since historic waters can only be treated as internal waters or territorial seas, and cannot be included within the EEZ or continental shelf. As a result, historic rights over the waters within the U-shaped line generate ambiguity and lack a clear interpretation as to how China views sovereignty around the line in regard to the existing law of the sea. ${ }^{139}$

However, if China argues for the ownership of the barren islands that are only located in remote sea areas away from its mainland, it is important to examine the following points. First, whether these geophysical structures (Paracels and Spratlys) may be characterized as islands forming territories or 'rocks' ${ }^{140}$ incapable of sustaining human habitation and incapable of maintaining their own economic life. Second, whether these structures generate territorial sea, EEZ, and continental shelf relies on the settlement of the first question. The geophysical structure in the SCS is composed of both 'islands' and 'rocks.' 'Island' is defined in UNLCOS as a "naturally formed area of land, surrounded by water, which is above water at high tide." ${ }^{141}$ 'Rocks' are of two categories: one is capable of sustaining human habitation and economic life of their own; the other is incapable of sustaining human habitation and economic life of their own. The UNCLOS has not differentiated between 'islands' and 'rocks' of the first category. The Convention recognized these

135 Waters seaward of the baseline, out to the maximum of 12 nautical miles, are territorial seas, while those shoreward of the baseline are internal waters. See UNCLOS art. 7.

136 Jinming \& Dexia, supra note 33 at 292.

137 Id. at 292.

138 Judge Jiuyong Shi of ICJ doubted on the existence of historic waters in the continental shelf/EEZ, and according to him until 1950s EEZs were considered to be the high seas. See Jiuyong Shi, Maritime Delimitation in the Jurisprudence of the International Court of Justice, 9 CHINESE J. INT'L L. 289 (2010).

139 Supra note 38, at 141.

140 UNCLOS art. 121(3).

141 Id. art. 121 (1). 
structures as territories capable of establishing territorial sea, EEZ, and continental shelf. 'Rocks' of the second category do not have EEZ or continental shelf. ${ }^{142}$ While several claimant countries in the region attempted to build structures on submerged rocks and reefs in order to establish a new maritime zone, ${ }^{143}$ it is true that the Paracels and Spratlys are partly and temporarily inhabited, fulfilling the criteria for generally being characterized as islands that form territories within the meaning of UNCLOS. ${ }^{144}$ Regardless of the question of who holds the legal title of the contested islands in the SCS, it must be noted that EEZ, beyond the territorial sea, remains to be legally used by all other States with certain restrictions.

In EEZ, coastal States enjoy exclusive rights concerning exploitation of marine resources, as well as the right to regulate on matters related to marine environment. However, coastal States also bear the responsibility to pay 'due regard' to the rights and duties of other States. ${ }^{145}$ The rights and duties of other States are embodied in Article 58 of UNCLOS. According to the provision, all States have the right to freedom of navigation and overflight in the air space above EEZ, as well as the right to other lawful uses of the sea not detrimental to the rights of the coastal States. ${ }^{146}$ Coastal States are not granted any specific authority over military activities, including surveillance in EEZ, either in terms of the right to regulate and enforce rules in relation to the military activities of other States, or of their own right to conduct military activities in EEZ. ${ }^{147}$ Unlike in the territorial sea where military exercises and weaponry testing were explicitly declared contrary to innocent passage, ${ }^{148}$ no such equivalent restrictions are articulated concerning EEZ or other maritime zones. The right of a coastal State to prevent or control military activities that occur within its EEZ remains controversial. ${ }^{149}$ Even though the precise nature of the military activity that may be conducted within EEZ is contested, it appears as though some naval activities that do not interfere with coastal States' rights are permissible. ${ }^{150}$

Based on the above analysis, it can be argued that China's 'historic title' leaves

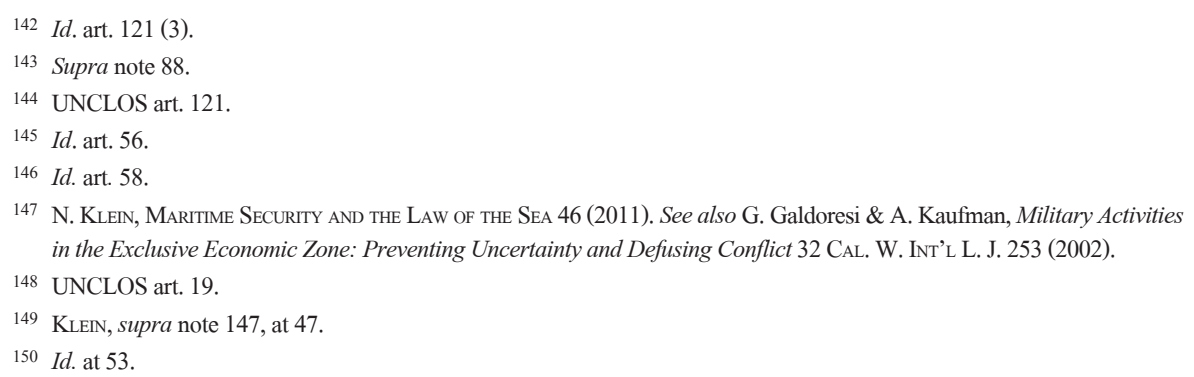


room for ambiguity in terms of sovereignty over the waters surrounded by the U-shaped line. In addition, the US and other nations have always enjoyed their right to freedom of navigation, as designated by the law of the sea. This assertion suggests that within the framework of the law of the sea, China, in the event that its sovereignty on the disputed islands is established, can only have maritime zones, such as territorial sea, EEZ, and continental shelf, around the islands. In this case, as a non-coastal State in the SCS, the US does have legitimate rights to conduct certain activities in the EEZ around those islands recognized by the law of the sea. Even though the US is not a party to UNCLOS, it accepted most of the provisions of the Convention as customary law. Therefore, the rights to freedom of navigation and to conduct other lawful activities in the EEZ of the SCS (albeit with 'due regard' to the rights of the coastal States) are designated as legitimate rights of all other States, including the US. Despite the fact that on several occasions, China has taken a stance for the prohibition of US military activities in the EEZ of the SCS and on its air space above, a 'general understanding' in UNCLOS suggests that there is no such restriction. ${ }^{151}$ Accordingly, the US military exercises in the EEZ of the SCS and on the air space above do not contravene the rules of the law of the sea. ${ }^{152}$

\section{Conclusion}

This article examined US-China relations in the context of disputes over the SCS. Two sets of legal disputes directly or indirectly affect the relations between them. The first set of disputes concerns overlapping sovereignty claims over the islands and waters of the SCS by the surrounding nations of the sea. The second set of disputes concerns the exercise of certain legitimate rights of other States (including the US) in the maritime zone of the SCS in accordance with the law of the sea. While the US is not directly linked to the first set of disputed questions, it has indirect interests in the economic, strategic and security fields. That is why the US pushes the nations concerned to a peaceful settlement of the disputes for the maintenance of regional peace and stability. The dynamics of a new world order, especially after the September 11 incident, has propelled the US to strengthen its hegemonic influence all across the globe, including in the SCS. It has also led the US to get involved in the disputes. However, as a non-coastal State in the SCS, the US is directly involved

\footnotetext{
151 Id. at 48.

152 Supra note 23, at 26.
} 
in the second set of disputes, which is about China's claim of 'historic rights,' and the restraining of the rights of the other States in the SCS. Since the legal basis of China's claim of 'historic rights' has not been explicitly supported by either general international law or UNCLOS, the author would conclude that the US, as a non-coastal State, can enjoy the pertinent rights, such as the right to freedom of navigation and other lawful rights, specifically in the EEZ of the SCS. These are provided by the law of the sea, albeit with a duty of paying 'due regard' to the rights of the coastal States. Consequently, China-US relations pertaining to the SCS disputes, despite the existence of geopolitical interests, are fundamentally guided by the values and principles of UNCLOS. 
